\title{
Pengaruh Struktur Kepemilikan, Likuiditas Dan Leverage Terhadap Financial Distress
}

\author{
Novi S. Budiarso \\ (Email: novi_sbudiarso@yahoo.com)
}

\begin{abstract}
The purpose of this study was to determine the variables that contribute to financial distress at the manufacturing company. Another aim is to conclusion the solution for the financial distress, relation to the variable-variable: institutional ownership, liquidity and leverage.

This study uses secondary data obtained from Indonesia Stock Exchange (BEI). During period 2010 to 2011. Data used in this study include financial ratios and ownership structure ratio. The statistical methods used to test the hypothesis is logit model.

The results of this study indicate that variable institutional ownership have a significant positif to financial distress, liquidity have a significant negative to financial distress, while leverage have no significant effect to financial distress
\end{abstract}

Keywords: Financial distress, Leverage, Liquidity

\section{Latar Belakang}

Berdasarkan trade off theory, perusahaan bisa mendapatkan keuntungan dengan menaikkan tingkat utang melalui manfaat pajak, karena biaya bunga merupakan biaya pengurangan pajak. Namun jika perusahaan menaikkan tingkat utang diatas titik tertentu maka tingkat financial distress akan mulai meningkat dan biaya yang berhubungan dengan utang tidak akan lagi menjadi keuntungan bagi perusahaan.

Faktor-faktor lainnya yang merupakan pemicu tingkat risiko seperti keadaan ekonomi yang tidak menentu dan makin meningkatnya lingkungan persaingan menyebabkan perusahaanperusahaan yang tidak beradaptasi dengan faktor-faktor ini akan mengalami financial distress. Apabila hal ini dibiarkan, maka perusahaan akan mengalami kebangkrutan.

Terdapat perbedaan definisi antara kebangkrutan dan financial distress menurut Platt dan Platt (2006). Financial distress adalah keadaan dimana tiga faktor sebagai berikut terpenuhi yaitu negative EBITDA, negatif EBIT dan negative net income. Masih kurang jelas saat dimulainya atau berakhirnya financial distress. Sebelumnya Platt dan Platt (2002) mendefinisikan financial distress merupakan suatu kondisi dimana keuangan perusahaan dalam keadaan tidak sehat atau sedang krisis. Atau dengan kata lain financial distress merupakan suatu kondisi dimana perusahaan mengalami kesulitan keuangan untuk memenuhi kewajibankewajibannya. Disamping itu terdapat berbagai tingkatan atas financial distress. Hal ini yang mendorong peneliti untuk melakukan penelitian sehubungan dengan pengaruh faktor-faktor yang mempengaruhi financial distress baik dari segi struktur kepemilikan maupun keuangan. Hal ini penting untuk melakukan prediksi kelangsungan hidup perusahaan.

Penelitian ini berusaha menjawab pertanyaan, apakah struktur kepemilikan, likuiditas dan leverage memberikan kontribusi terhadap kemungkinan terjadinya financial distress? Dan apakah berdampak terhadap solusi financial distress? 


\section{Tinjauan Pustaka}

Financial distress adalah suatu kondisi dimana perusahaan menghadapi masalah kesulitan keuangan. Menurut Platt dan Platt (2002), financial distress didefinisikan sebagai tahap penurunan kondisi keuangan yang terjadi sebelum terjadinya kebangkrutan ataupun likuidasi. Menurut Wurck (1990) financial distress adalah suatu keadaan dimana arus kas operasi tidak mencukupi untuk memenuhi kewajiban-kewajiban lancarnya seperti hutang dagang atau biaya bunga (Alyabel, 2002).

Beberapa penelitian tentang kebangkrutan dengan fokus pada penggunaan rasio keuangan sebagai prediktor financial distress. Altman (1968) menggunakan Z score sebagai alat untuk memprediksi probabilitas bankruptcy. Ohlson (1980), Zmijewski (1984) dan Lau (1987) menggunakan model prediksi yang sama tapi dengan rasio keuangan yang berbeda.

Dengan adanya kepemilikan institusional, investor cenderung akan lebih percaya terhadap perusahaan tersebut dan hal ini menjadi nilai tambah tersendiri bagi perusahaan tersebut. Schleifer dan Vishny (1986). Hasil penelitian Crutchley (1999) menyatakan bahwa kepemilikan institusional berpengaruh negatif terhadap financial distress perusahaan. Hal ini berarti bahwa peningkatan kepemilikan institusional dalam perusahaan akan mendorong semakin kecilnya potensi kesulitan keuangan. Keadaan tersebut disebabkan semakin besar kepemilikan institusional akan semakin besar monitor yang dilakukan terhadap perusahaan yang pada akhirnya akan mampu mendorong semakin kecilnya potensi kesulitan keuangan yang mungkin terjadi di dalam perusahaan.

Fan et al (2013) menyajikan bukti bahwa perilaku financial distress berhubungan dengan faktor institusional eksternal. Lingkungan institusional seperti struktur kepemilikan dan kualitas pemerintah, sangat mempengaruhi keputusan atas distress perusahaan. Perusahaan dengan kepemilikan dan perusahaan dengan efektivitas yang lemah menunjukan kinerja dan operasional yang buruk.

Rus et al (2013) yang melakukan penelitian hubungan struktur kepemilikan dengan financial distress, menyatakan bahwa kepemilikan oleh Government linked investment companies tidak memiliki hubungan yang signifikan dalam menjelaskan financial distress. Sedangkan kepemilikan non government linked investment companies secara signifikan positif berhubungan dengan financial distress. Sedangkan Domestic Private Institutional Investor (DPIIs) memiliki hubungan signifikan postitif terhadap financial distress. Penelitian ini beranggapan bahwa hal ini menjelaskan bahwa semakin tinggi kepemilikan oleh institusional privat semakin rendah financial distress karena peranan sebagai agen yang berfungsi untuk melakukan monitoring.

Penelitian tentang identifikasi financial distress perusahaan yang dilakukan oleh Khaliq et al (2014) menunjukkan adanya hubungan yang signifikan antara current ratio dan debt ratio terhadap Z-Scores yang mendeterminasikan financial distress atas Government Linked Companies (GLC). Keuangan negara yang tidak sehat akan menjadi penyebab distress jangka panjang dimana akan mengakibatkan pembatasan atas aktivitas investasi, arus modal dan kinerja perusahaan.

John (1993), melakukan penelitian terhadap hubungan antara likuiditas dengan proksi dari biaya financial distress seperti Tobin's q, R\&D dan biaya iklan, dan probabilitas kebangkrutan. John menyatakan terdapat hubungan positif antara likuiditas dan financial distress costs. Selain itu hasil penelitian menyatakan hubungan negatif antara leverage dan financial distress costs, di mana utang diukur dengan total utang dan total utang jangka panjang. 
Opler dan Titman (2012) menyatakan bahwa perusahaan dengan leverage yang tinggi kehilangan pangsa pasar secara substansial dalam kompetisi keuangan. Selanjutnya dikatakan bahwa hal ini sejalan dengan pandangan bahwa biaya tidak langsung dari financial distress adalah signifikan dan positif. Perusahaan dengan tingkat leverage yang tinggi sehubungan dengan Research and Development adalah subjek yang paling mengalami distress secara ekonomi.

Penelitian yang dilakukan oleh Jiming dan Wei Wei (2011) menunjukkan bahwa leverage (debt asset ratio) berpengaruh positif dan signifikan terhadap kondisi financial distress. Sehingga ini berarti semakin besar kegiatan perusahaan yang dibiayai oleh utang semakin besar pula kemungkinan terjadinya kondisi financial distress, akibat semakin besar kewajiban perusahaan untuk membayar utang tersebut. Hasil yang sama juga ditunjukkan dalam penelitian Ong, et al. (2011) menyatakan bahwa leverage berpengaruh positif dan signifikan terhadap kondisi financial distress.

Pranowo et al (2010), menguji financial distress dengan membagi status kondisi keuangan, proses dari financial distress perusahaan secara integral ke dalam empat tahap yaitu: good, early impairment, deterioration and cash flow problem companies. Hasil penelitian menunjukkan bahwa current ratio, efisiensi, modal dan variable dummy dari status kondisi keuangan memiliki hubungan positif dan signifikan terhadap Debt Service Coverage (DSC) sebagai proksi dari financial distress. Sedangkan leverage memiliki hubungan negative dan signifikan dengan DSC. Faktor yang lain yaitu profit, laba ditahan, Good corporate Governance dan makroekonomi tidak memiliki pengaruh yang signifikan terhadap financial distress.

Baimwera and Muriuki (2014), dalam penelitiannya menyatakan bahwa berdasarkan analisis univariate dan multivariate guna menguji financial distress perusahaan, likuiditas dan leverage memiliki hubungan tidak signifikan dalam mendeterminasikan financial distress perusahaan. Dilain pihak pertumbuhan dan profitabilitas memiliki hubungan yang signifikan dengan financial distress.

\section{Hipotesis dan Model}

Perumusan hipotesis penelitian ini

$\mathrm{Ha}_{1}$ : Kepemilikan institusional berpengaruh signifikan negatif terhadap financial distress.

$\mathrm{Ha}_{2}$ : Likuiditas berpengaruh signifikan negatif terhadap financial distress.

$\mathrm{Ha}_{3}$ : Leverage berpengaruh signifikan positif terhadap financial distress.

\section{Metode Penelitian}

\subsection{Data}

Populasi dan Sampel. Populasi yang digunakan dalam penelitian ini adalah seluruh perusahaan manufaktur yang terdaftar di PT. Bursa Efek Indonesia (PT. BEI). Pemilihan sampel dilakukan dengan metode purposive sampling atau sampel bertujuan dengan kriteria tertentu. Kriteria penarikan sampel yang diterapkan adalah :

1. Perusahaan yang terdaftar di BEI pada tahun 2010 - 2011.

2. Semua perusahaan manufaktur sektor agriculture, mining, basic industry dan chemicals

3. Perusahaan yang memiliki data laporan keuangan untuk periode yang berakhir 31

Desember 2010-2011 dan data pendukung lain yang lengkap.

\subsection{Variabel dan Pengukuran Variabel}

Variabel dependen adalah financial distress yang merupakan variabel dikotomi (dichotomous dependent variables). Financial distress didefinisikan sebagai perusahaan yang 
memiliki Earning Before Interest and Tax (EBIT) negatif. Dalam penelitian ini variabel dependen disajikan dalam bentuk variabel dummy dengan ukuran binomial, yaitu nilai satu (1) apabila perusahaan memiliki EBIT positif dan nol (0) apabila perusahaan memiliki EBIT negatif. Variabel independen dalam penelitian ini adalah kepemilikan institusional, likuiditas dan leverage. Pengukuran variabel independen dan dependen menggunakan proksi sebagai berikut :

1. Kepemilikan Institusional adalah pemegang saham berbentuk instansi/pemerintah yang tidak aktif dalam kegiatan operasional perusahaan. Kepemilikan institusional diformulasi sebagai berikut:

$$
\text { Kepemilikan institusional }=\frac{\text { Jumlah saham yang dimiliki institusional }}{\text { Jumlah saham beredar }} \quad X 100 \%
$$

2. Likuiditas, rasio yang digunakan dalam penelitian ini adalah current ratio yang merupakan rasio yang menunjukkan kemampuan perusahaan dalam memenuhi kewajiban finansial jangka pendeknya dengan menggunakan aktiva lancarnya

$$
\text { Liquidity }=\frac{\text { Current Asset }}{\text { Current Liabilities }}
$$

3. Leverage adalah tingkat sampai sejauh mana hutang digunakan dalam struktur modal suatu perusahaan.

$$
\text { Leverage }=\frac{\text { Total Long Term Debt }}{\text { Total Asset }}
$$

\subsection{Metode Analisis}

Metode analisis yang digunakan untuk menguji hipotesis dalam penelitian ini adalah regresi logistik (Logistic Regression), dimana variabel bebasnya merupakan kombinasi antara metric dan non metric (nominal). Regresi logistik adalah regresi yang digunakan untuk menguji apakah probabilitas terjadinya variabel terikat dapat diprediksi dengan variabel bebasnya. Teknik analisis ini tidak memerlukan uji normalitas, heterokedastisitas, dan uji asumsi klasik pada variabel bebasnya (Ghozali, 2006).

Variabel dependen yang digunakan dalam penelitian ini merupakan variabel binary, yaitu apakah perusahaan tersebut mengalami kondisi financial distress atau tidak. Variabel independen yang digunakan dalam model ini adalah kepemilikan manajerial, kepemilikan institusional, likuiditas, dan leverage.

Metode analisis yang digunakan adalah Logit Regression Model. Menurut Maddada (1991) model logit regression tepat digunakan untuk kasus penyampelan dari dua populasi, yaitu perusahaan yang mengalami kesulitan keuangan dan perusahaan yang tidak mengalami kesulitan keuangan. Secara lengkap model tersebut dirumuskan sebagai berikut:

$$
\operatorname{Ln}(p / 1-p)=\text { DISTRESSEDt }=\beta 0+\beta 1 \text { Institutional }+\beta 2 \text { Liquidity }+\beta 3 \text { Leverage }+\varepsilon
$$


Pengujian hipotesis dilakukan dengan membandingkan hasil uji nilai signifikan $t$ (Sig t) dengan alpha. Adapun kriterianya adalah jika nilai sig $>$ alpha (0.05) maka Ho diterima, jika nilai sig < alpha (0.05) maka Ho ditolak.

\section{Hasil Analisis dan Pembahasan}

\subsection{Hasil Analisis}

Langkah pertama yang dilakukan ialah mengelompokan data perusahaan yang mengalami financial distress dan sehat. Lalu menghitung variabel independen, dan dependen. Dalam hal ini variable dependennya adalah financial distress, variabel independennya adalah Kepemilikan institusional, likuiditas dan leverage. Setelah itu melakukan pengujian secara statistik dengan uji kesesuaian model kemudian uji multikolineritas dan uji hipotesis (uji Wald), dan yang terakhir adalah uji ketepatan model.

Terdapat 3 (tiga) cara penilaian kesesuaian model regresi logistik dengan data yang ada. Ketiga cara tersebut menurut Ghozali (2009) yaitu dengan melihat penurunan nilai statistik -2 Log Likelihood, kenaikan nilai $\mathrm{R}^{2}$ Cox dan Snell/nilai $\mathrm{R}^{2}$ Nagelkerke, dan nilai probabilitas dari statistik Hosmer-Lemeshow.

Nilai -2 Log Likelihood Ratio dengan melihat penurunan nilai statistik -2 Log Likelihood. Penurunan nilai -2 Log Likelihood yang dimaksudkan adalah penurunan nilai sebelum dan setelah adanya variabel bebas dalam model. Selanjutnya selisih nilai -2 Log Likehood ini dibandingkan dengan nilai $\chi^{2}$. Tabel dengan selisih derajat kebebasan/degree of freedom (df). Derajat kebebasan yang dimaksudkan yaitu derajat kebebasan setelah penambahan variabel bebas $(\mathrm{df} 2)^{7}$ dan derajat kebebasan sebelum adanya penambahan variabel bebas $(\mathrm{df} 1)^{8}$. Apabila nilai selisih statistik $-2 \log$ Likelihood lebih besar daripada $\chi^{2}$ tabel, maka dapat dikatakan penurunan nilai statistik -2 Log Likehood signifikan, artinya penambahan variabel bebas ke dalam model memperbaiki kesesuaian model, Ghozali (2009).

Koefisien Cox dan Snell Square dan Nagelkerke R Square Cox dan Snell's R Square merupakan ukuran yang hampir sama dengan $\mathrm{R}^{2}$ pada multiple regression yang didasarkan pada estimasi likelihood dengan nilai maksimum kurang dari 1 (satu) sehingga sulit diinterpretasikan. Negelkerke's $\mathrm{R}^{2}$ merupakan modifikasi dari koefisien Cox dan Snell untuk memastikan bahwa nilainya bervariasi dari 0 (nol) sampai 1 (satu). Hal ini dilakukan dengan cara membagi nilai Cox dan Snell R dengan nilai maksimumnya, Ghozali (2009).

Hosmer dan Lemeshow's Goodness of Fit Tests, keputusan penolakan atau penerimaan hipotesis dilakukan dengan menggunakan tingkat signifikansi 5\%. Hosmer and Lemeshow's Goodness of Fit Tests menguji hipotesis nol bahwa data empiris cocok atau sesuai dengan model (tidak ada perbedaan antara model dengan data sehingga model dapat dikatakan fit. Menurut Ghozali (2009), goodness of fit test dapat dilakukan dengan memperhatikan output dari Hosmer and Lemeshow's Goodness of fit test, dengan hipotesis:

H0 : Model yang dihipotesiskan fit dengan data

HA : Model yang dihipotesiskan tidak fit dengan data

Jika nilai statistik Hosmer and Lemeshow sama dengan atau kurang dari 0,05 maka hipotesis nol ditolak yang berarti terdapat perbedaan signifikan antara model dengan nilai observasinya sehingga goodness fit model tidak baik karena model tidak dapat memprediksi 
nilai observasinya. Jika nilai statistik Hosmer and Lemeshow lebih besar dari 0,05 maka hipotesis nol tidak dapat ditolak dan berarti model mampu memprediksi nilai observasinya.

Tabel klasifikasi 2x2 menghitung nilai estimasi yang benar (correct) dan salah (incorrect). Pada kolom merupakan dua nilai prediksi dari variabel dependen dalam hal ini perusahaan sehat (1) dan perusahaan tidak sehat (0), sedangkan pada baris menunjukkan menunjukkan nilai observasi sesungguhnya dari variabel dependen. Pada model sempurna, maka semua kasus akan berada pada diagonal dengan ketepatan peramalan 100\% (Ghozali, 2005).

Pengujian signifikansi dari koefisien regresi pada regresi logistik digunakan uji Wald untuk menguji signifikansi konstanta dari setiap variabel independen yang masuk ke dalam model. Oleh karena itu, apabila uji wald terlihat angka signifikansi lebih kecil dari 0,05, maka koefisien regresi adalah signifikan pada tingkat kepercayaan 5\%. Dengan uji Wald, kita dapat mengetahui seberapa besar pengaruh variabel independen terhadap kemungkinan perusahaan berada pada kondisi financial distress.

\subsection{Pembahasan}

\subsubsection{Deskripsi Sampel Penelitian}

Tabel 5.1

Deskripsi Sampel Penelitian

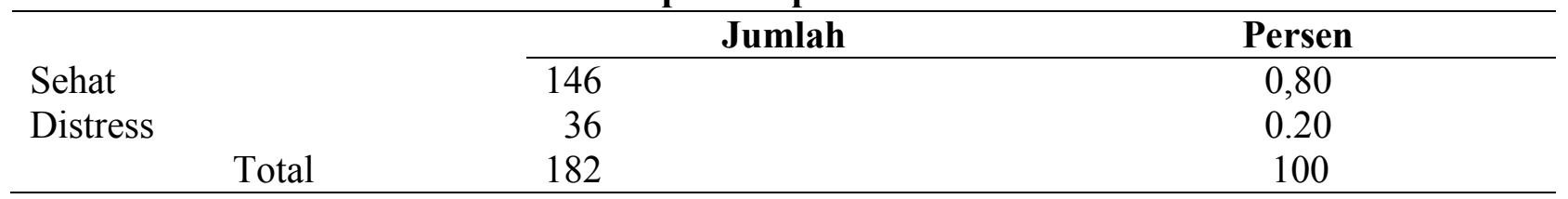

Berdasarkan kriteria-kriteria sampel yang telah ditetapkan maka diperoleh total sampel sebesar 182 perusahaan(lihat tabel 5.1.). 146 perusahaan masuk dalam kategori sehat dan 36 perusahaan dalam kategori distress. 


\subsubsection{Penilaian Kesesuaian Model (model fit test)}

Tabel 5.2

. -2 Log Likelihood Step

\begin{tabular}{cccc}
\hline & Iteration & & Coefficients \\
\hline & & -2 Log likelihood & Constant \\
\cline { 2 - 3 } Step 0 & 1 & 182.130 & 1.209 \\
& 2 & 181.035 & 1.390 \\
& 3 & 181.032 & 1.400 \\
& 4 & 181.032 & 1.400 \\
Step 1 & 1 & 164.554 & 1.460 \\
& 2 & 158.650 & 1.705 \\
3 & 157.673 & 1.726 \\
4 & 157.589 & 1.726 \\
6 & 157.588 & 1.726 \\
\hline
\end{tabular}

Hasil pada tabel 5.2 menunjukan nilai -2 Log likelihood block number $=0$ adalah 182.130 dan -2 Log likelihood block number $=1$ adalah 157.588. Penurunan ini menunjukan model regresi logistik yang lebih baik. Dapat disimpulkan bahwa penambahan variable kepemilikan institusional, likuiditas dan leverage ke dalam model, memperbaiki model fit regresi logistik.

Tabel 5.3

Omnibus Tests of Model Coefficients

\begin{tabular}{|c|c|c|c|c|}
\hline \multirow{3}{*}{ Step 1} & \multirow[b]{2}{*}{ Step } & Chi-square & df & Sig. \\
\hline & & 55.265 & 4 & 0.000 \\
\hline & Block & 55.265 & 4 & 0.000 \\
\hline & Model & 55.265 & 4 & 0.000 \\
\hline
\end{tabular}

Nilai Goodness of Fit Test dilihat dari uji Chi Square yang mempunyai nilai 55.265, dengan $\mathrm{df}=4$, (lihat table 5.3). Hasil tersebut berarti model regresi logistik layak dipakai untuk analisis selanjutnya. Hasil Chi Square didukung oleh nilai signifikansi $>0,05$. 
Tabel 5.4

Hosmer and Lemeshow's Goodness of Fit Test

\begin{tabular}{cccc}
\hline Step & Chi-square & df & Sig. \\
\hline 1 & 12.753 & 8 & 0.121 \\
\hline
\end{tabular}

Hasil pengujian (lihat Tabel 5.4) menunjukkan Chi-square sebesar 12.753 dengan nilai probabilitas signifikan sebesar $0.121>0,05$ maka hipotesis nol diterima. Hal ini berarti model regresi layak untuk digunakan dalam analisis selanjutnya, karena tidak ada perbedaan yang nyata antara klasifikasi yang diprediksi dengan klasifikasi yang diamati. Atau dapat dikatakan bahwa model mampu memprediksi nilai observasinya.

Tabel 5.5.

Hasil Pengujian Nagelkerke's R Square Model Summary

\begin{tabular}{cccc}
\hline & Cox \& Snell $\boldsymbol{R}$ & Nagelkerke $\boldsymbol{R}$ \\
Step & $\mathbf{- 2 ~ L o g ~ l i k e l i h o o d}$ & Square & Square \\
\hline 1 & $157.588^{\mathrm{a}}$ & 0.121 & 0.192 \\
\hline
\end{tabular}

Untuk melihat kemampuan variabel bebas dalam menjelaskan variabel financial distress, digunakan nilai Cox dan Snell $\mathrm{R}$ Square dan Nagelkerke $\mathrm{R}$ Square. Nilai Nagelkerke R Square sebesar 0,192 (lihat table 5.5.) yang lebih besar dari pada Cox dan Snell $\mathrm{R}$ Square, yang menunjukkan bahwa kemampuan ketiga variabel bebas dalam menjelaskan varians financial distress adalah sebesar $19.2 \%$ dan terdapat $80,8 \%$ faktor lain yang menjelaskan varians financial distress.

\subsubsection{Uji Multikolineritas}

Tabel 5.6.

Correlation Matrikx

\begin{tabular}{llllll}
\hline \multirow{3}{*}{ Step 1} & Constant & Constant & Institutional & Likuiditas & Leverage \\
\cline { 2 - 5 } & Institutional & -0.154 & -0.154 & -.374 & -.807 \\
& Likuiditas & -0.374 & 0.000 & 0.034 & 0.042 \\
& Leverage & -0.807 & 0.044 & 1.000 & 0.165 \\
\hline
\end{tabular}

Dari Tabel 5.6 dapat diketahui bahwa tidak ada terjadi multikolineritas antara variabel yang 1 dengan variabel lainnya karena hasil tabel uji menunjukkan nilai $<0,9$. 


\subsubsection{Uji regresi Logistik Biner \& Uji Hipotesis (Uji Wald)}

Tabel 5.7.

Uji Wald

\begin{tabular}{|c|c|c|c|c|c|c|}
\hline Variabel & B & S.E. & Wald & df & Sig. & $\operatorname{Exp}(B)$ \\
\hline Institutional & 3.480 & 1.494 & 5.423 & 1 & 0.020 & 32.462 \\
\hline Likuiditas & -0.001 & 0.000 & 4.935 & 1 & 0.026 & 0.999 \\
\hline Leverage & -0.696 & 0.530 & 1.728 & 1 & 0.189 & 0.498 \\
\hline Constant & 1.726 & 0.379 & 20.771 & 1 & 0.000 & 5.619 \\
\hline
\end{tabular}

Berdasarkan tabel 5.7 dapat dilihat bahwa nilai signifikansi kepemilikan institusional dan likuiditas $<0,05$ hal ini menunjukan H1 diterima, penelitian ini kontradiksi dengan penelitian Crutchley (1999), Fan et al (2013) dan Rus et al (2013). Pengujian atas H2 menunjukkan bahwa $\mathrm{H} 2$ diterima. Semakin rendah tingkat likuiditas semakin tinggi kemungkinan financial distress perusahaan. Hasil penelitian ini mendukung penelitian Khaliq et al (2014) dan John (1993). Nilai signifikansi leverage $>0.05$ menunjukan bahwa H3 ditolak.

\subsubsection{Uji Ketepatan Prediksi}

Tabel 5.8.

Clasification Table

\begin{tabular}{|c|c|c|c|c|}
\hline & \multicolumn{3}{|c|}{ Predicted } \\
\hline & & \multicolumn{2}{|c|}{ FD } & \\
\hline & & Distress & Sehat & Percentage Correct \\
\hline \multirow[t]{3}{*}{ Step 1 Distress } & Distress & 4 & 32 & 11.1 \\
\hline & Sehat & 2 & 144 & 98.6 \\
\hline & Overall Percentage & & & 81.3 \\
\hline
\end{tabular}

Dari Tabel 5.8. dapat dilihat bahwa prediksi perusahaan Distress berjumlah 36, hasil observasi menunjukan 32 perusahaan yang sehat sehingga ketepatan prediksi adalah 11.1\%. Prediksi perusahaan sehat berjumlah 146, hasil observasi menunjukan 144 perusahaan yang mengalami distress sehingga ketepatan prediksi 98.6\%. Ketepatan prediksi secara keseluruhan sebesar $81,3 \%$.

\section{Kesimpulan}

Hasil penelitian menunjukkan bahwa kepemilikan institusional dan likuiditas memiliki kontribusi terhadap financial distress. Sedangkan leverage tidak memiliki kontribusi terhadap terjadinya financial distress.

Artinya, solusi yang dapat diambil oleh perusahaan terhadap faktor kepemilikan institusional adalah perusahaan harus berusaha meningkatkan peran monitoring dari institusional guna meminimalisir perbedaan kepentingan manajer dan shareholder, sehingga makin bertambahnya kepemilikan institusional dapat mengurangi kemungkinan financial distress. Kepemilikan institusional dalam perusahaan jangan hanya menjadi alat untuk memenuhi tuntutan perundang-undangan dan hukum suatu negara, misalnya peraturan mengenai penerapan Good Corporate Governance. Sedangkan sehubungan dengan faktor likuiditas, perusahaan harus 
menjaga proporsi hutang lancar yang dapat dibiayai oleh aset lancar perusahaan. Jika tidak maka perusahaan akan masuk pada level financial distress dan selanjutnya akan mengalami kebangkrutan. Perusahaan tidak perlu melakukan restrukturisasi terhadap struktur modal. Karena struktur modal yang ada saat ini bukanlah pemicu financial distress.

Penelitian selanjutnya, disarankan menggunakan periode waktu yang lebih panjang sehingga data yang diperoleh lebih andal. Kemudian disarankan untuk melakukan pengujian tidak hanya terhadap pengaruh struktur institusional, tetapi juga terhadap struktur kepemilikan manajerial dan kepemilikan dewan direksi sehingga keseluruhan unsur struktur kepemilikan diuji secara keseluruhan dan diperoleh hasil untuk menentukan kepemilikan yang memberikan kontribusi terhadap financial distress.

\section{Daftar Pustaka}

Altman, E. 1968. Financial Ratios, Discriminant Analysis and the Prediction of Corporate Bankruptcy, XXIII(4), 589-609

Baimwera, B. and Muriuki, A. M. 2014. International Journal of Current Business and Social Science. Analysis of Corporate Financial Distress Determinants: a Survey Of NonFinancial Firms Listed In The NSE. 1(2), 58-80.

Browning, E. S. and Jonathan Weil, 2002, Burden of doubt: Stocks take a beating as accounting worries spread beyond Enron, Wall Street Journal, 39(5), 5-27

Fan, J. P. H., Huang J. and Zhu, N. 2013. Institutions, ownership structures, and distress resolution in China. Journal of Corporate Finance, 23, 71-87.

Jensen, Michael C, dan W.H. Meckling. 1976. Theory of the Firm : Managerial Behaviour, Agency Cost and Ownership Structure. Journal of Financial Economics. 3(4), 305- 360

John, T.A. 1993. Accounting measures of corporate Liquidity, Leverage and Costs of Financial Distress. Financial management. 22(3), 91-101.

Ohlson, J. 1980. Financial Ratios and the Probabilistic Prediction of Bankruptcy. Journal of Accounting Research 19, 109-131.

Khaliq, A., Altarturi, B. H. M., Thaker, H. M. T., Harun, M. Y., and Nahar, N. 2014. Identifying Financial Distress Firms: A Case Study of Malaysia's Government Linked Companies (GLC). International Journal of Economics, Finance and Management, 3(3), 141-150.

Pranowo, K., Achsani, N. A, Manurung, A. H. and Nuryartono, N. 2010. International Research journal of Finance and Economics. Determinant of Corporate Financial Distress in an Emerging Market Economy: Empirical Evidence from the Indonesian Stock Exchange 2004-2008. 52, 80-90.

Opler T. C. and Titman S. 2012. Financial Distress and Corporate Performance. The Journal of Finance. 4(3), 1015-1040.

Platt, H. and M. B. Platt. 2006. Understanding Differences Between Financial Distress and Bankruptcy. Review of Applied Economics, 2( 2), 211-227.

Platt Harlan D., Platt Marjorie B., (2002). "Predicting corporate financial distress: reflection on choice-based sample bias, Journal of Economics and Finance, 26(2), 184-197.

Rus, Md. R., Mohd. K. N., Latif, R. A. and Alassan, Z. N. 2013. Ownership Structure and Financial Distress. Journal of Advanced Management Science, 1(4), 363-367.

Wang, Z., dan X. Deng. 2006. "Corporate Governance and Financial Distress." The Chinese Economy 39(5), 5-27. 
Weiwei, D. dan Jimimg, L. 2011. An Empirical Study on the Corporate Financial Distress Prediction Based on Logistic Model: Evidence from China's Manufacturing Industry. International Journal of Digital Content Technology and its Applications. 5(6). 368-379.

Wruck, Karen Hopper, 1990, Financial Distress, Reorganization, and Organizational Efficiency. Journal of Financial Economics, 27, 419-444.

Zmijewski, M. 1984. Methodological Issues Related to Estimation of Financial Distress Prediction Models. Journal of Accounting Research, 22, 59-82. 